\title{
Participatory rural appraisal: A systems approach for identification of problems by an agro-ecosystem analysis
}

\author{
BASAVARAJAPPA ${ }^{1}$ AND RAJKUMAR* \\ Central Plantation Crops Research Institute, KASARGOD ( KERALA) INDIA \\ (Email : rajkumarcpcri@gmail.com)
}

\begin{abstract}
Participatory rural appraisal (PRA) technique of selected village (Bilakundi) in Belagum district of Karnataka state revealed that village basically sugarcane and maize based cropping system. The major sources of irrigation are open well, bore well and canal and 721 hectare of land is irrigated through these sources. The PRA tools used include transect walk, agroecological mapping, social mapping, resource map, mobility map, time trend, seasonal calendar, gender analysis, time line, livelihood analysis, technology mapping, wealth ranking, consequence diagram, problem solving tree etc. The major constraints identified were increasing micronutrient ( $\mathrm{Zn}-\mathrm{Fe}$ ) deficient fields, water salinity, water logging, market price fluctuation, water scarcity during summer, quality of electricity supply to run pump sets, timely non-availability of labourers for agricultural activities, infertility of buffalo and cows, root grub and woolly aphid insect pest problem in sugarcane and gradual declining of soil fertility. Based on the problems identified, suitable solutions were arrived in consultation with researchers, subject matter experts of KVK and progressive farmers.
\end{abstract}

Key Words :Participatory rural appraisal, Problem identification, Systems approach, Agro-ecosystem analysis, Field experience training

View Point Article : Basavarajappa and Rajkumar (2016). Participatory rural appraisal: A systems approach for identification of problems by an agro-ecosystem analysis. Internat. J. agric. Sci., 12 (1) : 123-133.

Article History : Received : 20.11.2013; Accepted : 24.12.2015

\footnotetext{
* Author for correspondence

Department of Biotechnology and Crop Improvement, Kittur Rani Chennamma, College of Horticulture (U.H.S.) ARABHAVI (KARNATAKA) INDIA (Email : crbasu@gmail.com)
} 